\title{
Mitosis in the Pollen Mother-cells of Acer negundo, L., and Staphylea trifolia, L.
}

\author{
BY \\ DAVID M. MOTTIER, \\ Professor of Botany in Indiana University.
}

With Plates IX and $\mathbf{X}$.

$\mathrm{D}$

URING the past three years the writer has been engaged, with more or less interruption, upon the study of the mitotic processes in the microspore mother-cells of species of Aceraceae and of Staphylea trifolia, L., of the Staphyleaceae, a family closely related to the Maples. In the native flora of Indiana, Staphylea trifolia, L., is the sole representative of the family. This paper will be confined, however, to the writer's observations on the mitotic phenomena in only one species of the genus Acer and to Staphylea trifolia, L., while the results obtained in other Maples will be reserved for a future publication.

In I909 Darling published the results of a study on the two divisions in the microspore mother-cells of Acer negundo, L., but, as will be seen from what follows, his conclusions differ widely in certain respects from those of the writer.

\section{ACER NEgundo, L.}

The resting mucleus. The resting nucleus of the pollen mother-cell at the beginning of the growth period reveals the presence of a sparse and delicate network upon which are distributed small chromatin granules, and a very distinct globular nucleolus. The nucleolus may or may not show the presence of vacuoles (Figs. 3,4). The chromatin granules are distinct, and stain definitely both with the triple stain and iron-alum-haematoxylin. The granules vary somewhat in size, and frequently tend to form small collections, as may be seen in Fig. 4. In fact, the larger granules are usually found to represent aggregates of smaller ones. The majority of these chromatin granules are arranged along the nuclear membrane, but they occur also upon the linin net which traverses the nuclear cavity. Very delicate linin threads frequently extend to the nucleolus, and sometimes 
chromatin granules are clustered about the same, as has been shown in the case of Lilium (Mottier, '07), and as probably occurs in spore mother-cells of all plants at the corresponding stage in development. In many cases, however, these threads are so delicate and so few that the nucleolus appears to lie in the centre of a perfectly colourless space. I find no support here for the theory of prochromosomes, as only rarely are pairs of granules seen, and when the same occur they are without doubt the result of chance. It is a matter of common observation in all nuclei of both vegetative and spore-bearing cells that larger granules are frequently found to be collections of smaller ones. The cytoplasm is of a uniform network, with fine granules (Figs. 3, 4, 5).

At the stage of the development of the anther from which Figs. 3, 4, and 5 were taken there is a sharp contrast in appearance between tapetal and spore mother-cells, due to the greater density of the cytoplasm of the former, in which the granules are finer and more closely arranged. The writer desires to emphasize the fact that, at the stage in question, the nuclei of the tapetal cells have precisely the same visible structure as that of the spore-bearing cells, namely, fine chromatin granules scattered upon a delicate linin net and a relatively large nucleolus (Fig. I), although there may be two nucleoli. One nucleus is present in each tapetal cell at this stage, but later, at about the time of synapsis, this nucleus divides, when each cell contains two. This binucleate condition of the tapetal cells is remarkably constant both here and in Staphylea, to be mentioned in a later paragraph (Fig. 2). At the binucleate stage the tapetal cells have enlarged somewhat, and their cytoplasm presents a more coarsely granular appearance.

From the stages of Figs. 3 and 4 the nuclear net becomes more pronounced. There seems to be a greater number of meshes with thicker strands, and the chromatin granules are larger. The nucleolus is unchanged in so far as I have been able to determine. Very soon the stage of Fig. 5 passes into synapsis.

During the period of development described in the foregoing or in the presynaptic stages, Darling asserts ('09, p. I 84) that the chromatin content is built up from material budded off from the nucleolus. The nucleolus, according to his view, gives off small spherical droplets, which migrate to the nuclear wall, where they diffuse out upon the linin to build up the spireme. Although small bud-like protuberances of the nucleolus are of frequent occurrence here and in other species of Acer examined by me, yet I cannot agree with Darling that this fact indicates that these budlike protuberances separate and diffuse out into the net to build up the chromatin. However, I do not deny that the nucleolus furnishes material for the chromatin, as I have given expression to this idea in earlier publications. When the nucleolus breaks up at a later stage, to be described below, it shows frequently bud-like protuberances, but this is merely 
a fragmentation in the disintegrating process of the nucleolus, which has been so often described for other plants. Darling claims (loc. cit., p. I 85) also that a spireme thread is well formed before synapsis, citing as evidence his Figs. 9, IO, and II. In this respect I am unable to accept his interpretation, as I find prior to synapsis no indication of a spireme thread such as he figures. It is my conviction that Darling has in this instance misinterpreted the sequence of steps in the process, an error which is so prevalent in cytological literature dealing with plants. His Figs. Io and I I are certainly post-synaptic stages if, as he claims, his Figs. I3, I4, and I 5 are post-synaptic. I do not consider the nuclear structure of Figs. 4 and 5 as spiremes, but a network with meshes of varying sizes. The structure shown in Fig. 5 now passes directly into synapsis (Figs. 6 and 7). From Fig. 6 it is seen that the nuclear network tends to accumulate towards one side of the nucleus, and this accumulation may or may not include within itself the nucleolus. In the gradual contraction of the nuclear network the chromatin granules are brought closer together, some of the smaller ones doubtless collecting into larger ones. Likewise, some of the delicate linin threads of the meshes will be united and others severed. The synaptic contraction is the initiation of the spireme, and as the spireme is seen to be present as soon as any indication of a loosening up of the densely contracted mass is evident, it is difficult to understand how a spireme could be formed from a network in any other manner. The most that can be said is that, as the net contracts into the synaptic mass, there is a tendency to form a spireme. This tendency is more pronounced in some nuclei than in others. I find no support for the doctrine of Lawson ('11) that synapsis is brought about merely by an enlargement of the cavity of the nucleus. There is no doubt whatever that we have to do with a real contraction or balling up of the nuclear network.

Figs. 7 and 8 represent the earliest stages of complete synapsis. The granules are densely massed, yet it can be seen that there are distinct granules. In Fig. Io the contracted mass appears to be made up of larger and coarser lumps. Although this cell is larger than Fig. 8 and the cytoplasm gives evidence of rounding off, yet it is not possible to say that Fig. Io is a later stage than Fig. 8, for the pollen mother-cells differ considerably in size, and there is considerable variation in the time of the rounding off of the cells. There is a possibility that fixation may be less perfect in cases like Fig. Io, as there may be different degrees of poor or faulty fixation. In Fig. 9 we have a stage in synapsis that is a little more advanced than that of Figs. 7 and 8. One large and one small nucleolus lie near the contracted mass, in which it may be clearly seen that a chromatin thread or spireme is in process of formation. At the stage of Fig. 9 the cell usually shows signs of rounding off at the corners preparatory to separation from the primary cell-wall of the mother cell (Fig. I I). In this, as in many 
other plants, the writer has found much variation in the time at which the first rounding off of the mother-cell is distinguishable, using the appearance of the synaptic mass as a guide. In the earliest stages of the contraction the cells are invariably polygonal, forming a compact tissue without any intercellular spaces (Figs. 7, 8). With the appearance shown in Fig. 8 the rounding off usually begins, and the same is evident in all cells as soon as the contracted ball has loosened up sufficiently to show clearly the definite spireme character (Fig. II). Whether the appearance of the first rounding off of the cells is due to a slight shrinkage caused by the reagents cannot be stated with certainty. It is possible, of course, that this may be true to a limited extent, for it not infrequently happens that the cells in one loculus may be noticeably or even badly shrunken, while those of the neighbouring loculus of the same anther will show perfect fixation.

As pointed out for other plants, the loosening of the synaptic mass is first manifested by the extension of loops or turns of the spireme into the nuclear cavity (Fig. II). These continue to spread out, and soon the entire chromatin cord is distributed throughout the nucleus, forming what is so well known as the hollow spireme: The larger portion of the spireme is probably arranged along the nuclear membrane, yet it also traverses the cavity in various directions, some portions following straight courses through the cavity, others being more or less looped or kinked. Fig. I2 represents the stage of the thick hollow spireme in section, not all of the nucleus being shown. The earlier steps in the formation of this spireme have shown that it is made up of a succession of chromomeres that are held in the linin. No longitudinal fission or double nature of the spireme is seen in this plant, although this fact is not a proof that a longitudinal fission may not have taken place, as is the general rule in plants, and as will be seen in Staphylea, to be described below. The fact that the spireme is seen as a single cord makes it easier to trace certain later steps in the mitotic process with much greater certainty than were the confusing feature of the diverging halves of the spireme present in longer or shorter stretches, as frequently happens in the Lilies and in other plants. At this stage the pollen mother-cell has separated from the primary cell-wall and has formed a soft, thick wall of its own. The nucleolus is still present, and it is about as large as in any preceding stage.

The formation of the bivalent chromosomes from the hollow spireme. The next series of steps in the process following the regular, thick, hollow spireme result in the formation of the bivalents from the same. This transition brings about certain changes by which the regularity in the disposition of the turns of the spireme is lost, and which give rise to the phenomenon known as the second contraction. In the second contraction the spireme is so rearranged that a part of it is more or less closely entangled into a knot near the centre of the nuclear cavity, from which extend somewhat 
radially loops and straight portions. In many cells in Lilium this arrangement of radiating loops and straight portions of the spireme from the central knot occurs with almost the regularity of a diagram.

In Acer negundo there is present the feature that represents the second contraction, but it does not appear with the regular radiating loops, save, perhaps, in rare cases. During this rearrangement the spireme loses, as a rule, its more regular course and uniform thickness. It shows a tendency in many cells to become relatively thick in some places and attenuated in others. The loops and turns become shorter and so arranged that a picture of the whole nucleus, or a thick section of the same, does not present the regularity of Fig. I2. The most regular appearance of the spireme observed just before the segmentation into the chromosomes is represented in Fig. I 3 . Here certain parts of the spireme extend in straight stretches from a somewhat centrally located entanglement, while other parts form longer or shorter loops, which may be variously twisted or kinked. The stage following Fig. 13 is shown in Fig. I4. In this we see that the spireme is at least partly segmented. This nucleus shows a much greater regularity in the arrangement of the chromatin than is usual, and I have selected such nuclei as illustrations for the reason that the parts may be clearly and definitely made out. It is evident that the spireme has segmented into pieces that are either straight or in the form of loops. Closely following upon the stage of Fig. I4 is that of complete segmentation shown in Fig. I5. The spireme, which gives no evidence of being double or longitudinally split, has segmented transversely into a number of pieces that were previously joined end to end to form that spireme. These pieces (Figs. I 5, 16,17 , and 18 ) are in the form of straight rods, closed or open rings, or loops. The parallel sides of the loops may be twisted about each other, sometimes tightly and closely, sometimes loosely, forming figure 8's, as has been described for other plants. Each loop, ring, U, or 8 represents a bivalent chromosome made of two somatic chromosomes which have not separated at the extremities representing the bend of the loop. A loop or a ring is, therefore, a continuous piece of the spireme composed of two somatic chromosomes (Figs. 17,18 ). Figs. 17 and 18 are tangential views of nuclei, while Figs. 15 and 16 are more nearly radial sections. A ring is formed when the two halves of a loop curve away from each other equally, leaving the free ends closely juxtaposed or touching, or even slightly overlapping, each other. The formation of a $U$ from a piece of the chromatin spireme is self-explanatory. Of course, a ring may not necessarily owe its form to a previously looped portion of the spireme. For example, the large ring in Fig. I7 may have arisen from a loop, the free ends of which have touched end to end by the bending of the two sides, while at the point of bending of the loop the other ends of the two somatic chromosomes have tended to pull apart; or two curved somatic chromosomes may touch at the 
free extremities. I hold the first alternative as the most probable. In any event, the large ring in Fig. I7 is not formed by the divergence of the halves of a longitudinally split spireme with the free ends adhering, for there is no longitudinal fission evident, and if the fission really exists this fact is not made apparent by the separation of the halves. Furthermore, all other evidence is against the view of the separation of longitudinal halves to make a bivalent. When the sides of a $U$ are twisted about each other, we have the familiar figure 8 form or the hour-glass shape. At one end of the 8 the free ends frequently overlap, while the other end may represent the bend in the loop. A glance at Figs. I5 to 18 shows that all the bivalent chromosomes are not rings, U's, or 8's. Some are composed of two straight or slightly curved rods that may be parallel side by side with or without any twisting about each other; or the two pieces may adhere at one end to form V's, cross each other to form X's, or two of the free extremities may diverge to form Y's. All of these familiar forms may be found in the same nucleus. It sometimes happens also that the two straight somatic chromosomes may lie in a straight line adhering end to end, a phenomenon found in various other plants. Now the bivalents that appear as two straight rods lying in contact side by side, or that form X's, \&c., did not necessarily arise from the spireme as loops, but were in all probability derived from those parts of the spireme that were straight, or even from the more closely knotted or entangled parts of the chromatin thread. However, they represent different lengths of the spireme that have approximated side by side, and not the halves of the same piece of the thread that had split lengthwise. It follows, therefore, that, if the spireme were split lengthwise, as is the case in many plants, each member of the bivalent or somatic chromosome would be composed really, if not visibly, of two halves that tend to separate during the anaphase, and that do separate from each other during the telophase. This separation, which is finally and fully brought about during the second division, is the equational division, because the chromosomes separating in the second division represent halves of somatic chromosomes produced by the longitudinal split. The approximation or the so-called pairing of two somatic chromosomes to form bivalents is not understood by the writer as a conjugation. The assumption that there is an exchange of material taking place at this step in the mitotic process is based upon purely hypothetical data. If there is an exchange of material between chromosomes, is there not greater opportunity for such an exchange in the spireme itself, or in synapsis, or even in the resting stage, when the chromatin is in its most finely divided state? A further statement of this point will appear below.

In the entire history of the nucleus from the stage of rest to the formation of the twelve bivalents, nothing is clearer to the writer than the fact that all of the bivalents are derived from the spireme; that no 
spireme is formed previous to synapsis; that there is no union of two spiremes either before, during, or after synapsis, and that the spireme is composed of the somatic chromosomes placed end to end. In Acer negundo a longitudinal fission is not observed with certainty. The writer is unable to accept the origin of the bivalents as described by Darling (loc. cit., pp. I85, I 86), who asserts that eight chromosomes come from the spireme, while five bud off bodily and full fledged from the nucleolus. As stated in a foregoing paragraph, Darling claims that the spireme itself is derived from the nucleolus by portions of the same which bud off and diffuse out into the linin, thus forming the chromatin thread, and that later five other bivalents separate from the nucleus by direct budding. I have expressed the view in earlier publications that the nucleolus contributes material to the nourishment of the cell, and it is not denied that the chromatin may receive some of this material, but I do not interpret the small bud-like protuberances of the nucleolus which are frequently observed in earlier and later stages of the first mitosis of Acer negundo, and in other species of Acer studied by myself, as representing the manner in which the nucleolus contributes material to the cell. In all stages up to that of the multipolar spindle, the nucleolus is present, and sometimes one or two smaller additional ones (Fig. II). Even after the segmentation of the spireme, when the full number of bivalents is present, and on into the multipolar spindle, the nucleolus is still on hand, and it is about as large, or sometimes larger than at an earlier stage (Fig. I6, 19). During the formation of the spindle, however, the nucleolus fragments usually into smaller bodies, and finally all traces of nucleolar material disappears, save small extra-nuclear nucleoli, which may be seen distributed throughout the cytoplasm. In some cases, just prior to the appearance of the multipolar spindle complex, the nucleolus may be seen to form large bud-like protuberances (Fig. 20 a), and this may be reasonably interpreted as the breaking up of the nucleolus. Previous to the formation of the spindle, one or more bivalent chromosomes are not infrequently found lying close to, or in contact with the nucleolus (Fig. 20 b), but in no case have I found anything to lead me to believe that any chromosome is formed bodily from the nucleolus.

The formation of the spindle. At the complete segmentation of the spireme into the chromosomes, the latter appear much larger than in succeeding stages. The halves of any given bivalent may be thicker than the spireme from which they have just been formed. This is doubtless due to a shortening which always follows soon after complete segmentation. The bivalents now become distributed throughout the nuclear cavity, where they are seen to be connected with each other and with the nuclear membrane by delicate threads. They now undergo the process of condensation by which their size is greatly reduced, and show a tendency to be distributed 
along the nuclear membrane. With the continual condensation of the chromosomes and their consequent reduction in size, there is developed about the nucleus the weft of kinoplasmic fibres which form the multipolar spindle complex (Fig. I9). The nuclear membrane fades from view as a sharp line or boundary, and in its place there appear the kinoplasmic fibres. In an earlier publication the writer has expressed the opinion that the nuclear membrane is changed into kinoplasmic fibres, a view he still holds. The nucleus gradually loses its regular globular form, because of the encroachment of the spindle complex, and the straightening out and convergence of fibres to form the several poles. In short, the entire process of spindle formation is identical with that repeatedly described by the writer for other plants.

The condensation of the chromosomes continues until the spindle is fully formed, at which time they have probably reached their smallest size. In the equatorial plate each bivalent appears usually in the form of two thick and somewhat rounded lumps, or they may be somewhat elongated in the form of rods (Fig. 22). As a rule the bivalents appear more nearly like the one in the centre in Fig. 22. They are generally closely crowded, and appear in the form of a disc in polar view. In the judgement of the writer twelve bivalents are present. Even with the relatively small number the form and arrangement make accurate counting difficult, under the most favourable conditions. In Fig. 2 I twelve bivalents and a nucleolus are seen. This figure was obtained from a multipolar stage of the spindle in which all the objects could be clearly made out by changing the focus. The chromosomes that lie above others in the focus are made darker. The members of two of the bivalents $(a$ and $b$ ) are not closely applied. If each of these were counted as two, fourteen would be the number. I have not been able to convince myself that the number is thirteen as stated by Darling. It is either twelve or fourteen.

In the mature spindle the poles may be pointed or broad as in Fig. 22.

Anaphase and telophase. The two members of each bivalent (the two somatic chromosomes) now separate in metakinesis, one going to each pole. On their way to the poles each is seen to be split lengthwise (Fig. 23). This split may sometimes be observed in the equatorial plate (Fig. 22), but, as a rule, no indication of the longitudinal fission is noticeable at this stage, and not always is it very evident during the anaphase. Having arrived at the poles the chromosomes are almost always found closely crowded together, giving the appearance of a compact mass of lumps. Later they separate and undergo to some extent the process of reticulation or alveolization by which each may elongate, becoming attenuated in certain places, but remaining thicker in others, and the nuclear membrane is formed. The thicker lumps or fragments are connected with each other by means of 
delicate threads, while the attenuated parts also appear as connecting threads. The result is that the daughter nucleus consists of a number of larger and smaller lumps, irregular in shape, and connected by anastomosing threads. During the process one or more nucleoli make their appearance in each daughter nucleus, at the same time extra-nuclear nucleoli are still present in the cytoplasm (Fig. 23). Each daughter nucleus consists, therefore, of a lumpy network, together with one or more nucleoli. The chromatin is distributed chiefly along the nuclear membrane (Fig. 24). A more detailed description of the formation of the nuclear membrane and the nuclear cavity or vacuole will be given below in connexion with Staphylea, which, on account of the larger size of the cells, is a more favourable object for the study of this phase.

The second mitosis. Whether the process of reticulation, alveolization, or fragmentation of the chromatin described in the foregoing; is carried to the finely divided state that is recognized as the resting condition, I am not able to state with certainty. This is held to be a matter of little theoretical importance, chiefly for the reason that in some plants the chromatin of the daughter nuclei reaches the finely divided state of a resting nucleus, while in others it does not. The daughter nuclei divide simultaneously, the spindles being formed as multipolar complexes which change to the bipolar form as has been described for many other plants (Fig. 25). In this cell, which is typical, the chromosomes have not as yet been brought into the equatorial plate. Each is composed of two lumps, and these pairs of lumps are assumed to be the two pieces formed by the longitudinal splitting of the somatic chromosomes on their way to the poles in the preceding mitosis. In this second mitosis the chromosomes are arranged in a regular compact plate at the mature spindle stage. During the process of spindle formation nucleoli are present, lying either among the spindle fibres or out in the cytoplasm (Fig. 25). The granddaughter nuclei are formed in a manner similar to those of the first mitosis. The four nuclei are connected by systems of connecting fibres, before celldivision takes place as in many other Dicotyledons (Figs. 26 and 27). All four granddaughter nuclei are alike, both as to the nature and amount of chromatin and the presence of nucleoli.

\section{STAPHYLEA TRIFOLIA, L.}

In certain important respects, Staphylea is a more favourable object for a study of mitotic processes than Acer negundo and other species of Acer now under investigation, partly because of the larger size of the cells and nuclei, and partly because of the clearness with which other and secondary phenomena are brought to view. I have decided to present the details of each separately, rather than to combine the corresponding steps under common headings. This is done because of the greater ease with which the 
more essential differences can be followed by those who have not made a study of the subject at first hand, but whose work, though along different lines, requires a rather clear understanding of the essentials concerning which there is much difference of opinion even among those who have been extensively engaged in the study of mitotic phenomena. I have also abstained from the use of numerous new terms that have crept into cytological literature during the past decade, because I believe that much of the new terminology is not only not necessary to a clear statement of the phenomena, but that a number of the new terms have tended more to confuse than to elucidate.

From the resting mucleus to the hollow spireme. The sporogenous cells of Staphylea, at the beginning of the growth period, and after the same has fairly begun, form a compact and uniform mass of polygonal cells without any intercellular spaces. Fig. 28 is typical of the cells at this stage. The large nucleus presents a large number of chromatin granules of varying sizes distributed rather uniformly along the periphery, and also within the cavity upon a delicate linin network. I say upon a linin net, because I do not interpret the delicate and colourless threads connecting the distinctly stained granules or collections of granules as merely drawn out threads of chromatin substance. Within the cavity of the nucleus is the very large nucleolus. The nucleoli in these cells are comparatively free from the small bud-like protuberances met with in $A$. negundo, and in other species of Maples. There is not what the writer would regard as the semblance of a spireme or spiremes, but only a net. The structure shown in Fig. 28 passes directly into synapsis. This consists in the collection into a compact mass of the network and granules. In Fig. 29 the contraction or balling up is going on, the majority of the granules having collected about the nucleolus, partly enclosing it. In Fig. 30 we have complete synapsis. In this plant the nucleolus is very frequently not included within the mass, but may be found entirely outside, and sometimes removed a short distance from the mass of chromatin. In sections of anthers at the stage of complete synapsis, the large nucleoli lying without the balled-up mass is a very noticeable phenomenon when a section of an entire loculus is viewed with low powers. Figs. 28, 29, and 30 were drawn from the same section of the same loculus, the condition of Fig. 30 prevailing in one end of the anther pocket, and that of Fig. 28 in the other. Between the two ends are found all gradations from Fig. 28 to Fig. 30. Figs. 28 and 29 belong to neighbouring cells.

With further progress the contracted mass begins to loosen up, and it is seen that a spireme has in the meantime been in the process of formation (Fig. $3 \mathrm{I}$ ). As a rule the cell begins to round off when loosening up is initiated, as stated for $A$. negundo, but, as in that plant, there is some variation in the time. In Fig. 3I the cell had not rounded off, but other cells in the same loculus presented a rounding off at the corners. As the spireme 
in the contracted mass loosens up, it is seen in some cases to be double, or to show the longitudinal split as in the Lilies, but this phenomenon is of less frequent occurrence here. If the longitudinal fission is constant, it is not always recognizable, for in the fully developed and regularly distributed spireme the presence of a longitudinal fission is rather the exception (Figs. $3^{2}, 33$ ). Fig. $3^{2}$ is a slightly older stage than Fig. 3 I. The cell has well rounded off, and more of the spireme is distributed in the nuclear cavity. Fig. 33 represents the stage in which the spireme has reached its most uniform distribution. The nucleolus is large and presents a uniform structure, although what is usually interpreted as vacuoles may sometimes be seen within it. Small bud-like protuberances of the nucleolus are much less frequent here than in Acer negundo and some other species of Acer. The cytoplasm of the cell presents a rather uniform appearance. It sometimes happens that the condition of Fig. 33 may by shrinkage appear like that of Fig. 32, and thus be taken for a much earlier step in the process. Care must be taken, therefore, to distinguish between good and faulty fixation in this as well as in other mitotic stages.

As in $A$. negundo, there now takes place the rearrangement of the spireme, or second contraction, which ushers in the cross-segmentation and the formation of the bivalents. Here we have a nearer approach to the loops and straight portions of the spireme extending out or radiating from a more centrally placed knot or close entanglement of the spireme that is found in Lilium. The knot or entanglement (Fig. 34) may or may not include the nucleolus, and instead of one such entanglement there may be two or more. This figure represents a thick section of a nucleus, of which the nucleolus lay in a neighbouring section. At this stage there is much twisting and kinking of the thread. As a rule the nucleus presents a much more confused picture than Fig. 34. Transverse segmentation has undoubtedly begun, although certain free ends and short pieces shown in the figure have been made by the knife in sectioning. Because of the tangled condition of the thread and of the number of shorter and longer pieces to be observed, this is one of the most difficult steps in the entire mitotic process in which to obtain a clear view of all details. The spireme, in many cases at least, is more slender than in the stage just preceding, its diameter being much thicker in some parts than in others. It seems also a more sensitive stage, as shrinkage of the cells is frequent. In fact the entangled, twisted, and knotted parts of the thread are so confused that it is extremely difficult to make out clearly and definitely all details.

When segmentation is complete there soon follows a shortening and thickening of the chromosomes. The bivalents separate, becoming more regularly spaced in the nuclear cavity, and the form of each is clearly revealed (Figs. 35, 36, 37). The condition of Fig. 34 is frequently present in one or two loculi of an anther, while in the others that of Figs. $3^{6}$ and 37 
prevails. The different forms of bivalents observed in Staphylea are the same as those described for Acer negundo, with the exception that they are much larger and more numerous. Fig. 35 represents a median section of a nucleus, while tangential views of nuclei of the same loculus are represented in Figs. $3^{6}$ and 37. In Fig. $3^{6}$ the long piece of chromatin seems to indicate delayed segmentation. Such phenomena are frequent at this stage. $a, b$, and $c$, Fig. $3^{8}$, represent three sections that include the entire nucleus. The different sizes and shapes of the bivalents and the presence of the large homogeneous nucleolus are typical. In a two bivalents were pushed out of the nucleus in sectioning. Nothing is more striking at this stage, in this as well as in all other plants studied by the writer, than the perceptible differences in the size of the chromosomes, and if such differences have any significance in plants, there is, at the present state of our knowledge, no means of knowing. Since the various forms of the bivalents are the same as those of $A$. negundo, further details in this respect seem unnecessary.

Effort was made to ascertain accurately the number of chromosomes, but, because of the larger number and of their crowding together at the stages favourable for counting, I was unable to convince myself that the exact number was determined beyond question. In my judgement the haploid number is about thirty-six, or three times the haploid number of Acer negundo. Thirty-six was also the number ascertained for Acer rubrum. In either case it does not seem probable that the number exceeds forty or forty-two. Correlated with this larger number in Staphylea and in other species of Acer, is the much larger size of the pollen mother-cells than in Acer negundo with its twelve or fourteen bivalents.

When the chromosomes are distributed in the nuclear cavity following their formation, they may be connected with each other, with the nuclear membrane, and with the nucleolus, by very delicate threads (Fig. 35). In more densely stained cells these threads are distinct, but if the staining be less dense they appear faintly or not at all.

From spindle to telophase. The chromosomes now undergo a condensation until they are arranged in the equator of the spindle, when they have attained their minimum size (Fig. 39). The process of spindle development is similar to that in other pollen mother-cells. As described for the Lilies and other Dicotyledons, the kinoplasmic fibres may sometimes appear first as a weft running parallel with the nuclear membrane, and at a distance midway between the latter and the cell-wall (Fig. 35). The fully developed spindle is usually sharply pointed at the poles and the various fibres have the usual well-known arrangement. A polar view of this stage shows that the bivalents are arranged in the form of a circular disc (Fig. 40). They are usually more closely crowded together than in this figure. By looking at Fig. 40 it might seem that the task of counting is an easy one, and that accurate results may be obtained without difficulty, but such is by no 
means the case. The members of the bivalents take the form of short lumps. The rods which are fastened to the spindle fibres at one end may lie parallel with the spindle axis or at right angles to it. A glance at Fig. 39 will show how, in polar view, one member of a bivalent may obscure or partly conceal a neighbouring bivalent, and if, as almost always happens, the two halves of a bivalent do not lie closely applied to each other, each half may appear as a whole chromosome. Likewise the close arrangement of the segments as they pass to the poles is also an element to interfere with strict accuracy in counting. A comparison of Figs. 35 and 37 with Fig. 39 shows that a very marked condensation has taken place in the chromosomes. At the spindle stage the difference in size among chromosomes is less than at previous stages.

A phenomenon worthy of note at the stages in question is seen in the zone of larger granules formed about the nucleus, and which later surrounds the spindle (Figs. 35, 39, and 40). At the stage of the loose, hollow spireme the cytoplasm is uniformly granular, with very small nucleolar-like bodies scattered throughout the cell, and later, as the chromosomes approach the poles, the cytoplasm presents again a more uniform appearance in regard to the distribution of granules upon its network. To these granules may be applied Strasburger's term 'trophoplasm ', but in so doing the writer does not intend to convey the idea that trophoplasm is necessarily alveolar in structure. In pollen mother-cells these granules do not represent alveolae at all. They are merely amorphous particles held within the cytoplasmic network. In Fig. 33 we have this somewhat uniformly appearing cytoplasmic network with the granules more evenly distributed, while in Figs. 35 and 39 there is present the same character of network, but the granules are more numerous in circumscribed areas. It may be true that more of these granules are present, but whether the granular matter has increased in quantity, or has merely become collected into the region in question from other parts of the cell, may be left an open question. In the spindle stage there appear also groups of globules in the cytoplasm lying in a plane with the nuclear plate (Figs. 39 and 40). These globules are not extra-nuclear nucleoli, but oil-drops which turn black with osmic acid, and from which the dark colour may be readily removed by hydrogen peroxide. The peculiarity about these globules is the position they occupy in the cell. Later they may disappear entirely (Fig. 4I).

The large nucleolus which is present at the stage of complete segmentation of the spireme into the chromosomes (Figs. 35, 38) has disappeared by the time the spindle is mature, and at this stage and during the anaphase the amount of nucleolar material demonstrable as extra-nuclear nucleoli is very meagre. It is perfectly clear that the nucleolar matter is not taken up by the chromosomes, because the latter undergo a very considerable diminution of size, presumably by a process of condensation, during the disappear- 
ance of the nucleolus. The nucleolus undoubtedly changes into a substance or substances that do not take chromatin stains, and I am further strengthened in the conviction, expressed in earlier papers, that the nucleolus not only supplies material for the chromatin, but also for other parts of the cell.

On their way to the poles the daughter chromosomes undergo the longitudinal fission, or it may be that they merely reveal the longitudinal split which had taken place in the spireme stage (Fig. 42). As they reach the poles they are closely crowded together, so closely that they often appear as a fused mass. In polar view they are seen to form a rather compact disc.

The construction of the daughter nucleus. The daughter chromosomes on approaching the pole are probably brought into close contact by the convergence of the spindle fibres, for it is very difficult to escape the conclusion that the fibres are the active agents in the disposition and movements of the chromosomes. The assembled chromosomes now come to occupy the position of the spindle poles. When this has been accomplished, they begin to separate gradually from each other. On the side of the mass towards the centre of the cell, the cytoplasm seems to withdraw, leaving a vacuoli-like space free from granules, and at the same time a sharp boundary between the colourless space and the cytoplasm is seen, which is continued around the mass of chromosomes (Fig. 43). This cavity in which the chromatin now lies is the nuclear cavity, and its boundary is the nuclear membrane of the daughter nucleus.

As stated in the foregoing for Acer negundo, the chromatin collection separates into pieces irregular in outline, and connected by delicate anastomosing threads (Fig. 44). This figure is a polar view of a stage a little later than Fig. 43. Each large piece of chromatin in this figure represents probably more than one daughter segment, and the larger ones doubtless undergo further fragmentation, or alveolization into smaller pieces. As is well known, the extent of the alveolization or fragmentation varies in different plants, extending in some, as in Pinus, to the finely divided state known as the resting nucleus. Fig. 45 represents a longitudinal section of a daughter nucleus from a neighbouring cell in the same section as that from which Fig. 44 was taken. The pieces of chromatin are smoother and more slender. I did not find a continuous chromatin spireme in the daughter nuclei. The chromatin in the daughter nuclei of Staphylea does not reach the finely divided state of the resting nucleus.

The details of the second mitosis are the same as those in Acer negundo. 


\section{Summary AND Conclusions.}

The resting nucleus of both Acer negundo and Staphylea trifolia consists of a delicate linin network, or reticulum, upon which are distributed chromatin granules or collections of chromatin granules of varying sizes, and a large nucleolus.

Before synapsis there is no chromatin spireme present, nor is there any structure referable to any definite spireme or spiremes.

Synapsis is a normal phenomenon, and consists in the contraction of the nuclear reticulum into a more or less compact mass, which may or may not include the nucleolus.

Within the synaptic mass, and during the loosening up of the same, the definite chromatin spireme is formed. The assembling of the granules of the nuclear network into the contracted mass probably represents the initiatory step or steps in the formation of the spireme. The spireme is formed by the serial arrangement of the chromatin granules or groups of granules into a row of chromomeres, and furthermore by the union of certain meshes of the network along with the severing of others. This seems to be the only way a continuous thread of spireme can be formed from a network.

In Acer negundo the spireme appearing immediately on the loosening up of the synaptic contraction does not show a longitudinal split, which, however, may be observed in Staphylea at this and at later stages. Taking all of the pollen mother-cells into consideration, the appearance of the longitudinal split is probably the exception rather than the rule even in Staphylea. The view accepted here is that the spireme has undergone a longitudinal fission. If the chromomeres do not split lengthwise, they must be formed or assembled into the spireme as a double row instead of as a single row of granules; for there is no fusion of two spiremes, either before, or during, or after synapsis. In the opinion of the writer, the formation of the spireme is more probably the cause of synapsis than that synapsis is the cause of the formation of the spireme.

In both species there is finally developed the uniform hollow spireme, which is either endless, or, if free ends are present, these are few in number. This spireme consists of the diploid number of chromosomes placed end to end.

In both, there is present the feature known as the second contraction, or rearrangement of the spireme from the more regular to a more complicated form, in which are to be seen knotted and entangled parts, from which may extend a varying number of straight portions or loops. The looping is more frequent in Staphylea than in Acer negundo, where radiating loops from an entanglement may only rarely occur. There is not the regularity 
of radiating loops extending from a central entanglement as is characteristic of Lilium.

During the complicated rearrangement the cross-segmentation of the spireme begins. Portions of the spireme, more especially those appearing as loops, may segment into pieces equal to two somatic chromosomes or a whole bivalent, but all the pieces or segments which result from the transverse separation do not represent whole bivalents.

The looped portions usually form the rings, U's, or 8-shaped bivalents, while the separated somatic chromosomes make up the X's and the rods lying in contact side by side. In any and all cases where the two members or halves of bivalents lie side by side, these forms are due to the approximation side by side of the respective halves that were end to end in the spireme.

All chromosomes are formed from the chromatin spireme. Chromosomes do not bud off bodily and full-fledged from the nucleolus.

The number. of bivalents is probably twelve in Acer negundo, and thirty-six, or thrice this number, in Staphylea. The larger number of chromosomes seems to be correlated with the larger size of the pollen mother-cells in these two plants.

The spindle is developed according to the accepted multipolar type, which becomes later bipolar.

In Staphylea especially, a marked zone of granules (trophoplasmic granules) appears about the nucleus during spindle formation and persists until the anaphase, when the entire cytoplasm is again more uniform in appearance. Collections of oil-drops are very frequently present, lying in the plane of the nuclear plate. Later they disappear.

On their way to the poles the daughter segments are seen to be split lengthwise.

During the construction of the daughter nuclei and later the chromosomes undergo a fragmentation, reticulation, or alveolization into lumps or fragments of varying sizes, which are connected with each other by anastomosing threads. The finely divided state of the chromatin characteristic of resting nuclei of similar size was not observed in the daughter nuclei. A continuous, smooth and uniform spireme was not observed in the daughter nuclei prior to their division.

The second mitosis presents nothing unusual for Dicotyledonous plants. There is no unequal distribution of chromatin to the granddaughter nuclei.

The nucleolus represents material which contributes to the building up of the constituents of the cell. It doubtless serves as nutrition for both chromatin and cytoplasm, according to the demand made upon it by the activities of the different parts of the living substance. 


\section{PUBlicAtions REFERRED TO.}

As a discussion of the literature would greatly exceed the limits of this paper, only those contributions will be listed to which direct reference is made.

Darling, Chester A. ('09) : Sex in Dioecious Plants. Bull. Torr. Bot. Club, vol. xxxvi, I909, pp. I 77-99.

Lawson, A. Anstruther ('11): The Phase of the Nucleus known as Synapsis. Trans. Roy. Soc . Edin., vol. xlvii, 1911, pp. 591-604.

Mottier, D. M. ('97) : Beiträge zur Kenntniss der Kernteilung in den Pollenmutterzellen einiger Dikotylen und Monokotylen. Jahrb. f. wiss. Bot., vol. xxx, 1897, pp. 169-204.

('07): The Development of the Heterotypic Chromosomes in Pollen Mother-cells. Ann. Bot., vol. xxi, 1907, pp. 309-47.

('09): On the Prophases of the Heterotypic Mitosis in the Embryo-sac Mother-cell of Lilium. Ann. Bot., vol. xxiii, 1909, pp. 343-52.

\section{EXPLANATION OF PLATES IX AND $\mathrm{X}$.}

\section{Illustrating Professor Mottier's paper on Mitosis in the Pollen Mother-cells of Acer negundo, L., and Staphylea trifolia, L.}

All figures were drawn from sections with the aid of the Abbe camera lucida with Zeiss apochromatic immersion $2 \mathrm{~mm}$., apert. I·40, and compensating ocular I2. Magnification about $\times 2,400$.

\section{Acer negundo, L.}

Fig. I. Tapetal cell during the early growth period of pollen mother-cells.

Fig. 2. Tapetal cell at a later stage. The nucleus has divided. At the stages of Figs. I and 2 the nuclei show a structure identical with that of the young pollen mother-cells.

Figs. 3 and 4. Young pollen mother-cells, showing typical structure of nucleus and cytoplasm.

Fig. 5. Sligbtly older than Figs. 3 and 4 , showing nuclear structure just prior to synapsis.

Fig. 6 . The beginning of synapsis.

Figs. 7 and 8. Complete synapsis. In both cases the nucleolus has not been included in the balled-up network.

Fig. 9. The synaptic mass is beginning to loosen up, and a spireme is becoming visible.

Fig. Io. A similar stage, in which the details are much less distinct. The synaptic mass is seen from the edge, or its more indefinite lumpy nature is partly due to the reagents. The cell has just begun to round off.

Fig. II. A later stage in the loosening up of the synaptic mass. The cell has rounded off, but the new cell-wall was not evident in this case.

Fig. I 2. Complete hollow spireme at the stage of its greatest regularity and uniformity. The cell is provided with its new thick and soft wall. No longitudinal split is to be observed in the spireme.

Fig. I3. A step in what corresponds to the stage of the second contraction.

Fig. I 4. The spireme is partly segmented.

Fig. I5. Segmentation just complete.

Figs. 16,17 , and 18 . Later stages. Fig. 16 represents a thick radial section, while Figs. I 7 and 18 are tangential. At this stage the bivalents seem to have attained their maximum size. 
Fig. 19. Multipolar spindle. The bivalents have condensed into thick lumps.

Fig. 20, $a, b$. Showing manner of fragmentation of nucleolus just previous to, and during formation of, the spindle. At $b$ the nucleolus shows a small protuberance which is frequently seen at earlier stages. Near $b$ lies a bivalent chromosome, which might easily have been interpreted as a mass budding off from the nucleolus. One or more bivalents are frequently found touching the nucleolus, a phenomenon of frequent occurrence in plants.

Fig. 2I. Outline of a cell at the stage of the multipolar spindie : the chromosomes and nucleolus only were drawn. This is interpreted as containing twelve bivalents and the nucleolus. At $a$ and $b$ the halves of the bivalents are not closely applied. If, however, the two members of $a$ and $b$ are in themselves bivalents, there are fourteen bivalents. The former is held to be the more probable.

Fig. 22. Stage of the mature spindle, which often has broad poles. The chromosomes are unusually elongated in this cell. The usual form is shown by the chromosome at the middle. The two members of the chromosome at the right are probably at the point of separating, or metakinesis. An indication of the longitudinal fission of each daughter segment is visible.

Fig. 23. Anaphase; the daughter segments are now seen to be split lengthwise.

Fig. 24. Cell showing the two mature daughter nuclei connected by the connecting fibres. Two extra-nuclear nucleoli are present in the cytoplasm.

Fig. 25. The division of the daughter nuclei. The chromosomes have not been brought into the equatorial plate. When the spindle is mature, the chromosomes are arranged close together in a disc as in the first mitosis. Two nucleoli are present, one being derived from each daughter nucleus.

Fig. 26. Telophase of second mitosis. Extra-nuclear nucleoli are present in the cytoplasm.

Fig. 27. The four granddaughter nuclei have been formed, and all are connected by systems of connexion fibres. In respect to chromatin and nucleoli they all appear alike.

\section{Staphylea Irifolia.}

Fig. 28. Pollen mother-cell showing typical nuclear reticulum with its chromatin granules and the large nucleolus.

Fig. 29. Nucleus going into synapsis. The nucleolus is partly surrounded by the contracted reticulum.

Fig. 30. Synapsis completed. The nucleolus is almost free from the mass. The part of the reticulum extending over the nucleolus indicates the manner of spireme formation from the network or reticulum.

Fig. 3I. The synaptic mass has loosened up considerably and the spireme has been formed. In the straighter portions the longitudinal fission is seen; the halves, which are twisted about each other, have separated somewhat in the long stretch crossing the nucleus. At this stage the cell is frequently rounded off at the corners.

Fig. 32. The spireme spreading out in the nuclear cavity. The longitudinal split, if present, is not well marked. This is the usual appearance of the spireme at this and the next stage, Fig. 33 . The nucleolus lay in a neighbouring section.

Fig. 33. The complete hollow spireme with large nucleolus. Very small darkly stained bodies are usually present in the cytoplasm. The cytoplasmic reticulum immediately around the nucleus is finer meshed than out near the cell-wall.

Fig. 34. Nucleus showing second contraction. This represents a thick section of the nucleus. The looping is more regular and pronounced than is usually the case.

Fig. 35. All the bivalents have been formed and a large nucleolus is still present. The weft of kinoplasmic fibres running parallel with the contour of the nucleus is present midway between the latter and the cell-wall.

Fig. 36. Tangential section of nucleus showing bivalents. The long piece of the spireme may represent more than one bivalent.

Fig. 37. The same stage in radial section. The form of the bivalents is typical.

Fig. 38, $a, b, c$. Three sections including an entire nucleus in the same stage as the preceding figure. In $a$ two bivalents have been pushed out of the nucleus in the preparation of the section. These three figures show the variation in the size of the bivalents and the different disposition of the two members of each other that may exist in the same nucleus. 


$$
\text { Acer negundo, L., and Staphylea trifolia, } L \text {. }
$$

Fig. 39. The mature spindle of the first or heterotypic mitosis. Note the zone of coarser granules in the cytoplasm surrounding the spindle and the collections of oil globules in the plane of the equator.

Fig. 40. A polar view of the same stage, showing the thick lumpy form of the chromosomes and their arrangement in a circular disc or plate.

Fig. 4I. The close of the anaphase. The longitudinal split in the daughter segments is scarcely visible. Cytoplasmic granules more evenly distributed.

Fig. 42. One pole of the spindle at the close of the anaphase, showing details more distinctly. formed.

Fig. 43. One nucleus in a telophase of first mitosis. The nuclear membrane has just been

Fig. 44. A polar view of a daughter nucleus at a later stage than the preceding. The masses of chromatin of varying sizes are connected by numerous fine anastomosing threads.

Fig. 45. A longitudinal section of a daughter nucleus in about the same stage as Fig. 44 . 
Annals of Botany,

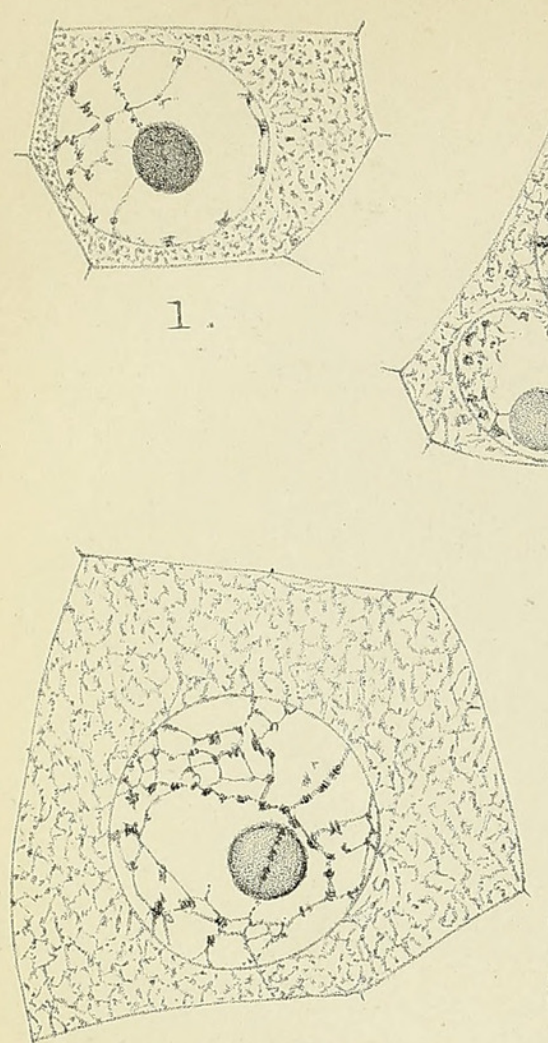

4.
2

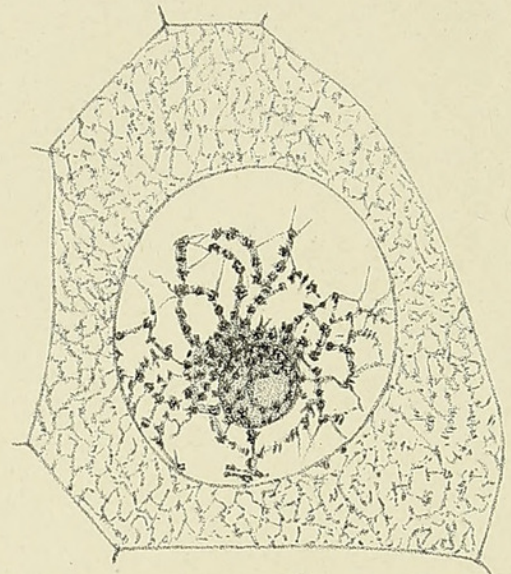

6.

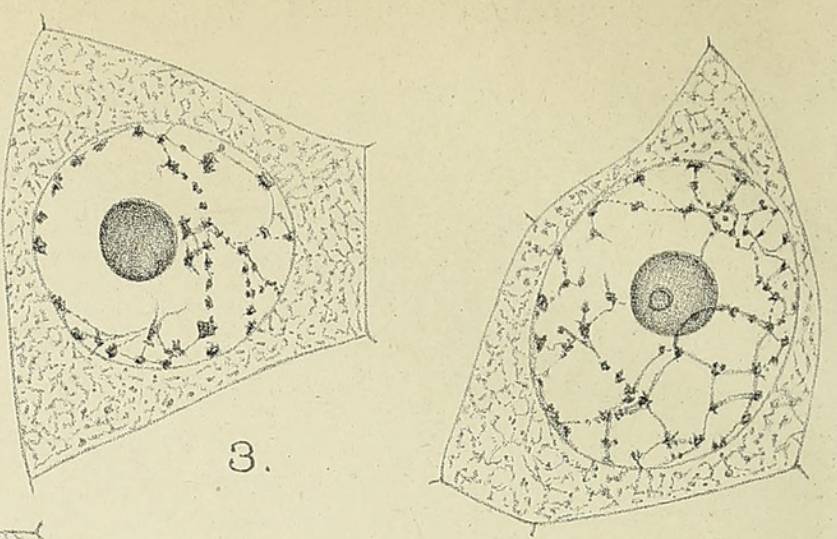

5.
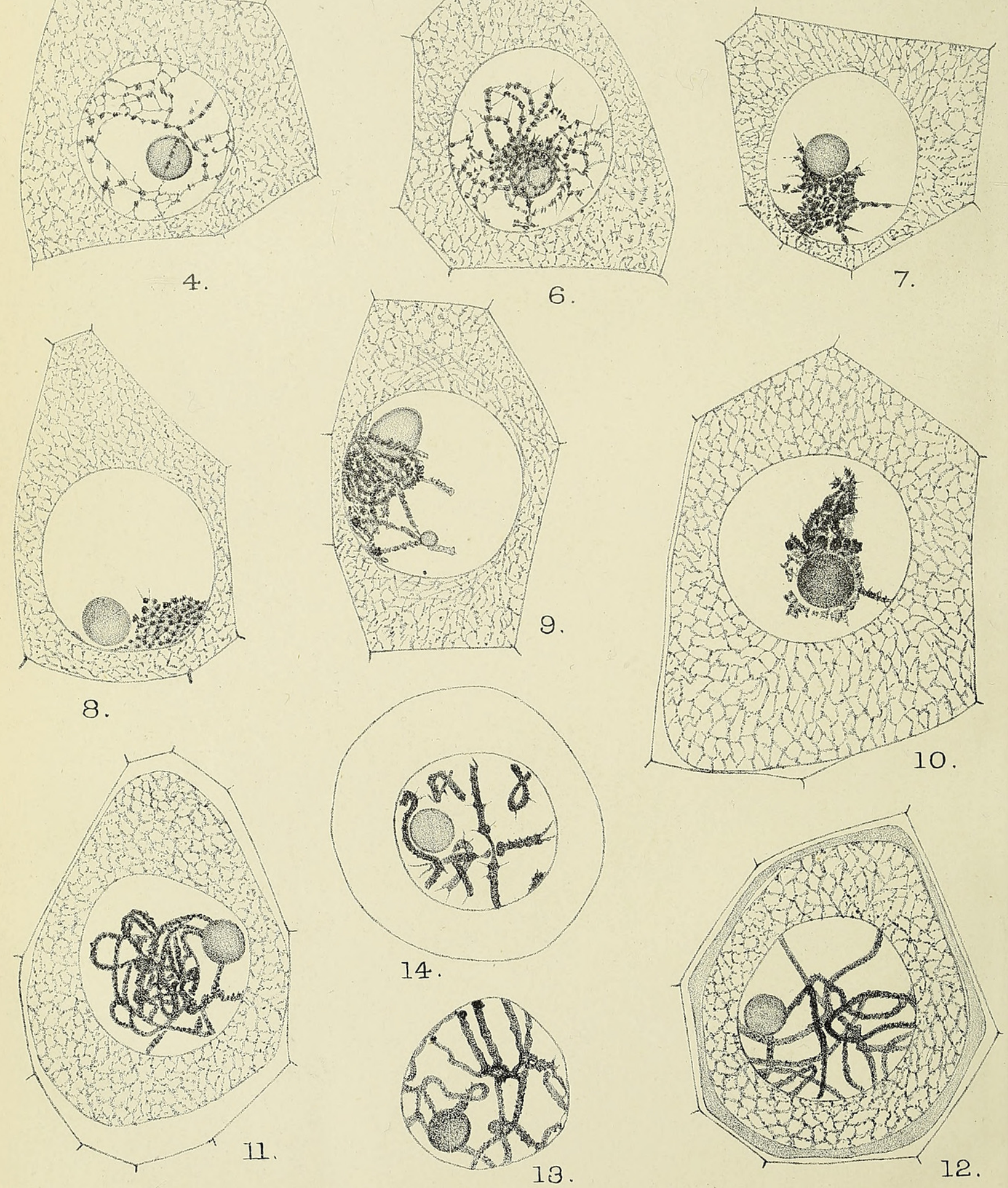

Mottier, adrat del. MOTTIER - MITOSIS IN POLLEN MOTHER CELLS. 
VoZ. XXVIII, PL.IX.

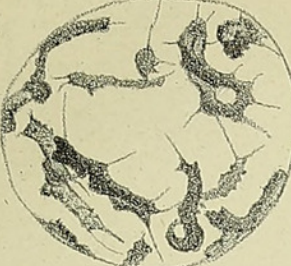

15.

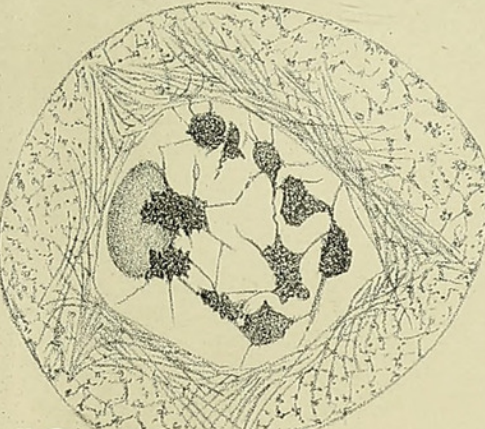

19.
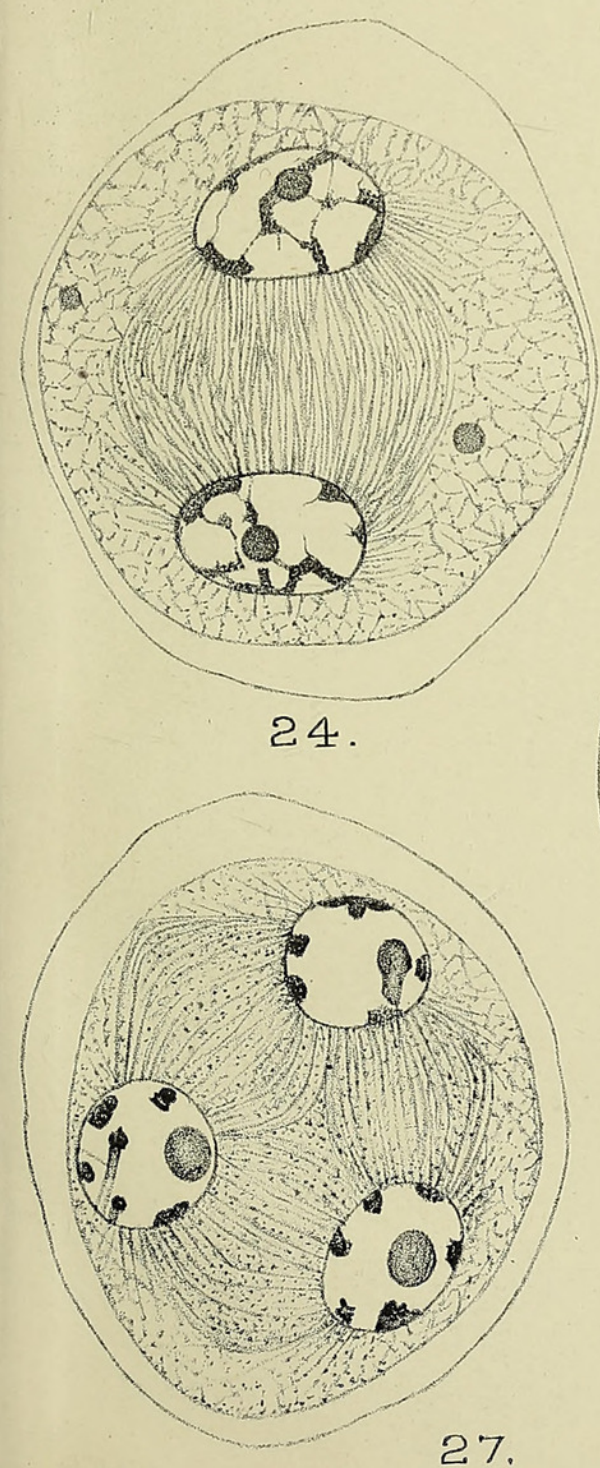
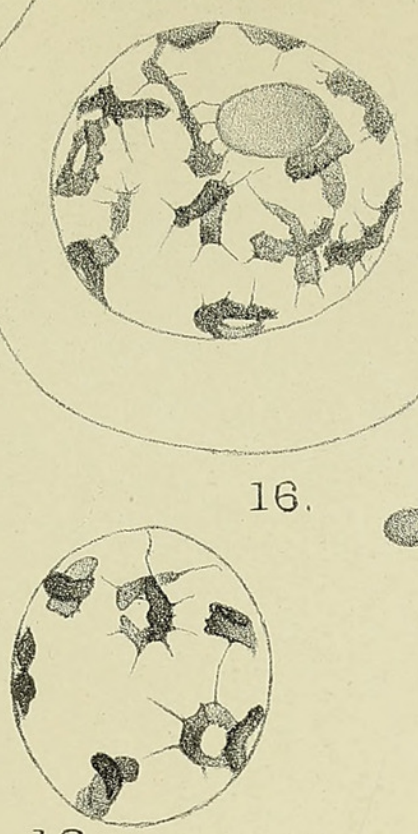

18.

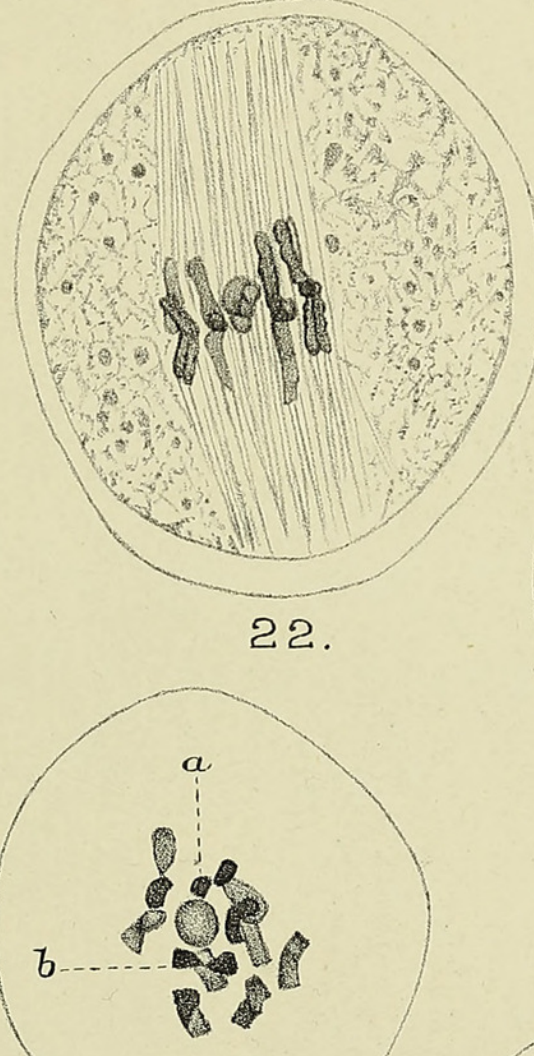

a 20 .
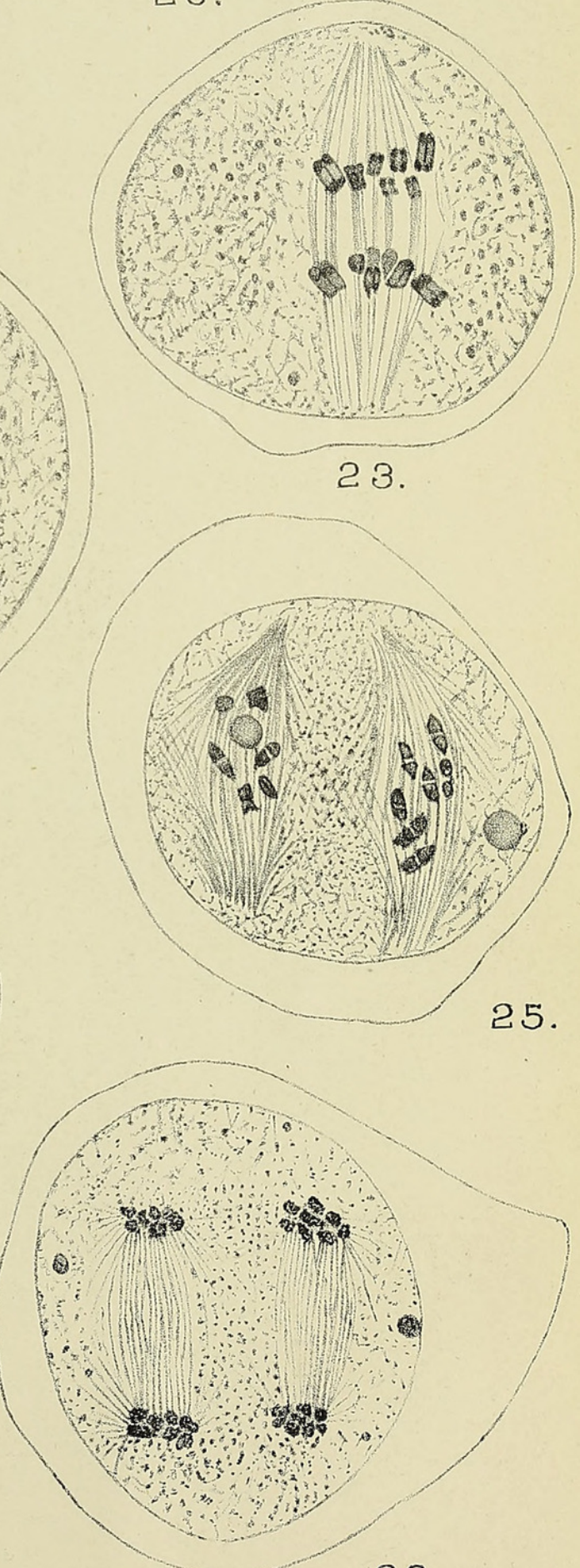

26.

Huth lith et ims 
Annals of Botany,
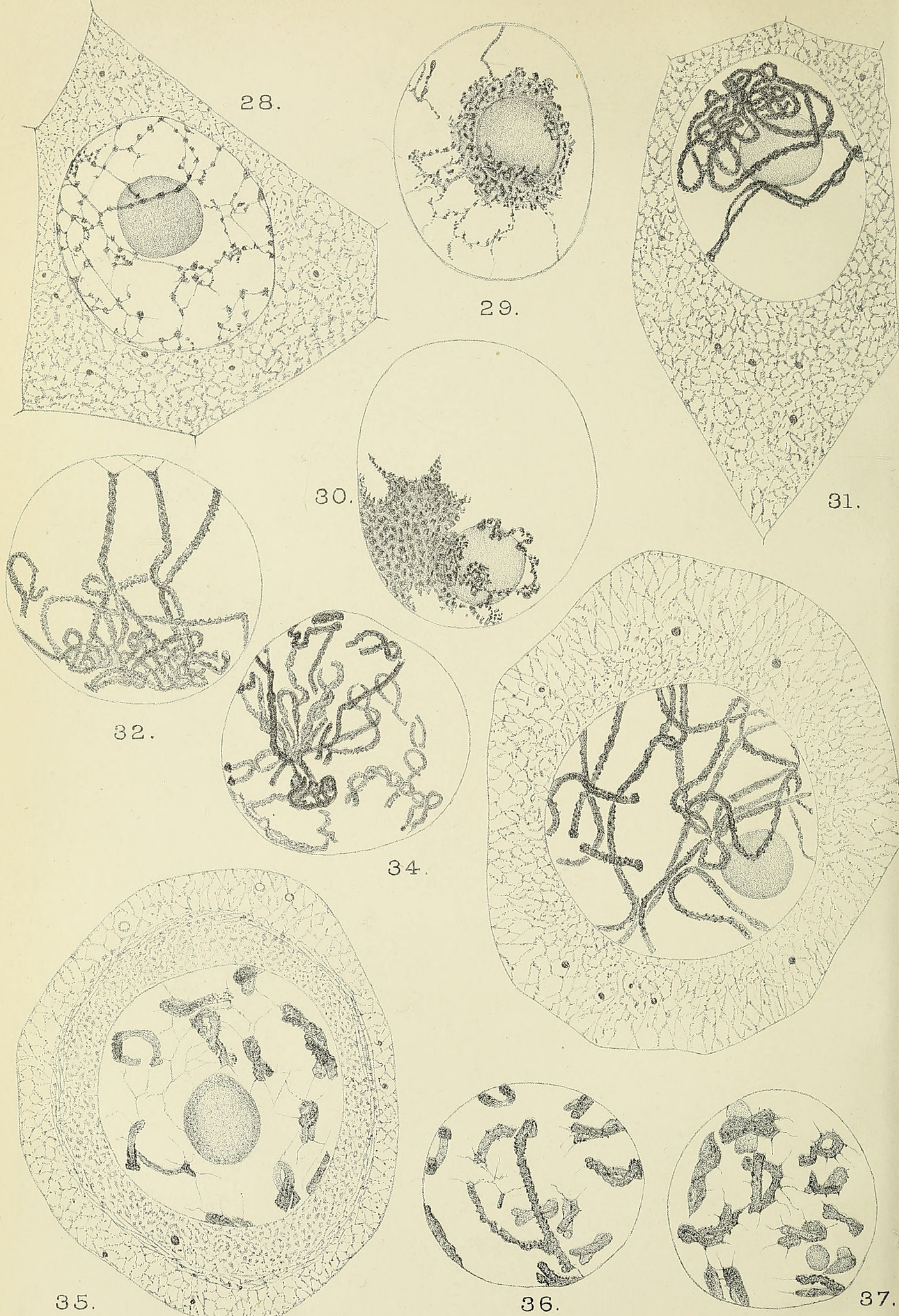

Mottiered ad nat del.

MOTTIER - MITOSIS IN POLLEN MOTHER CELLS. 


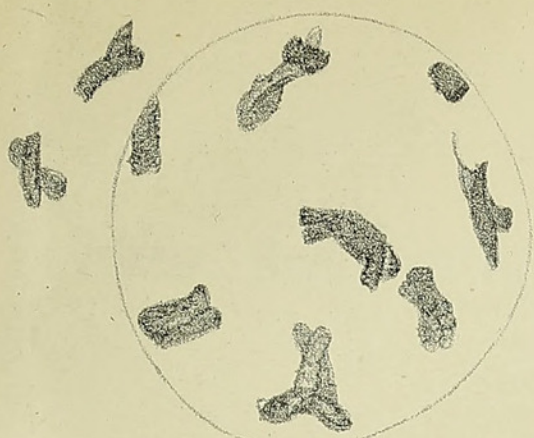

a.
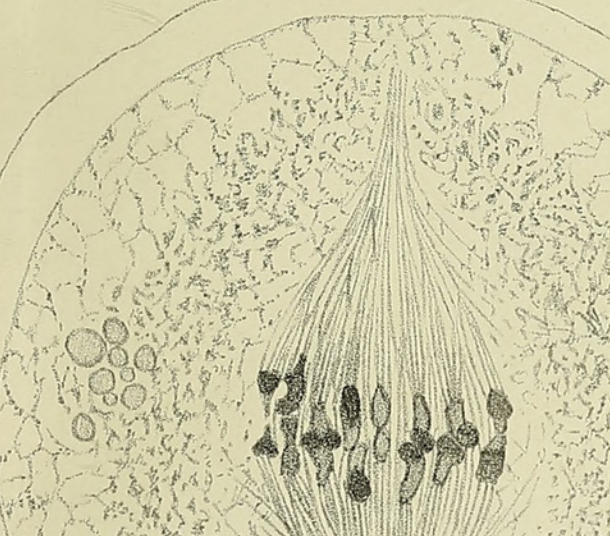

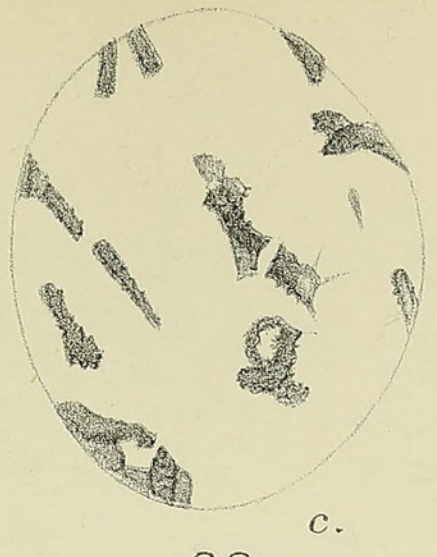

38.

Vol. XXVIII, PL.X.

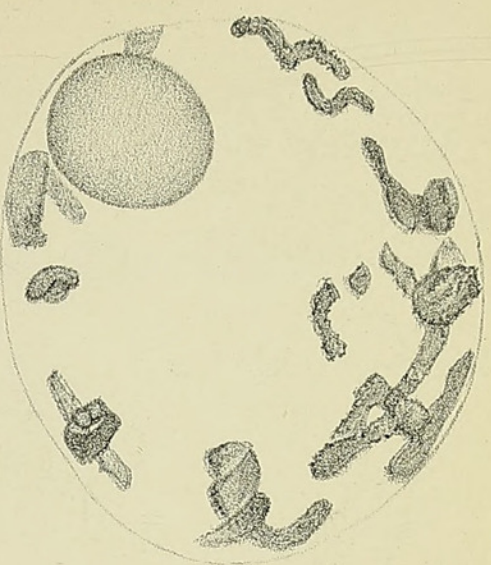

b.

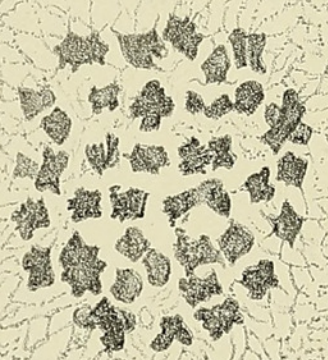

40.

42.

43.

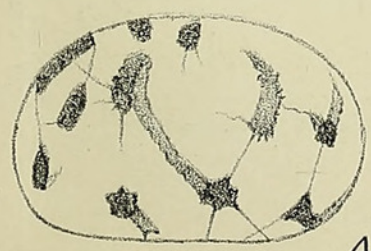

45.

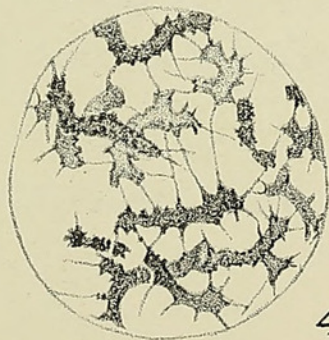

44

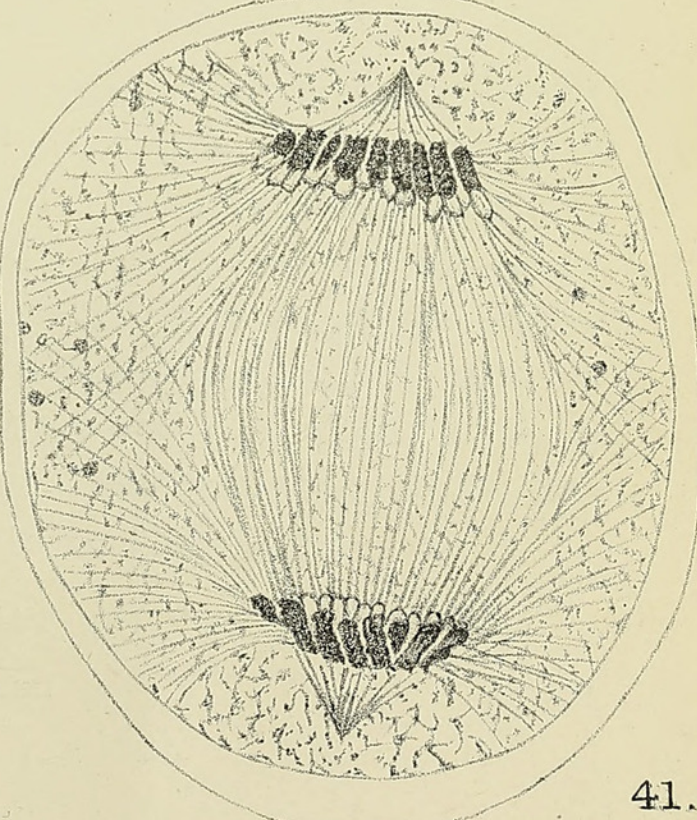

Huth lith et imp 
Annals of Botany,

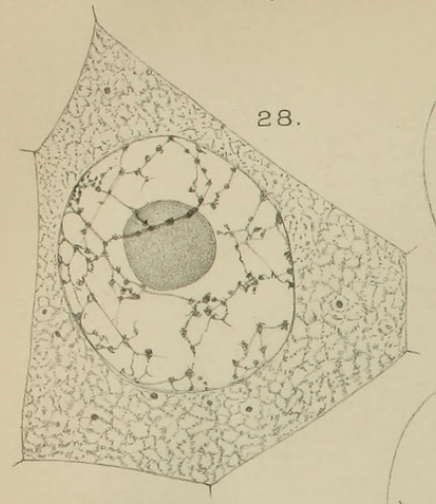

Sol 2)

32.
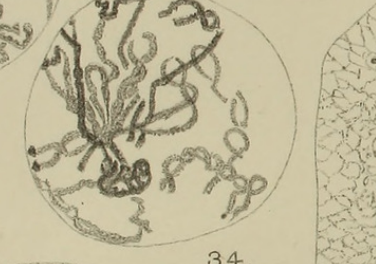

29.

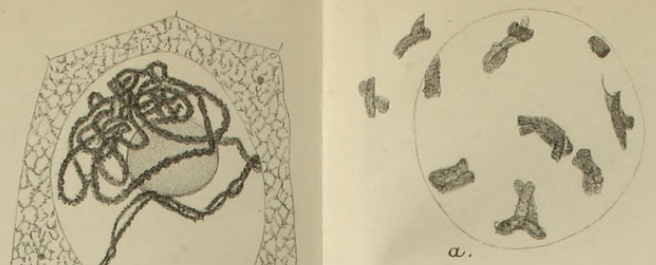

Vol. XXVIII, Pl.X
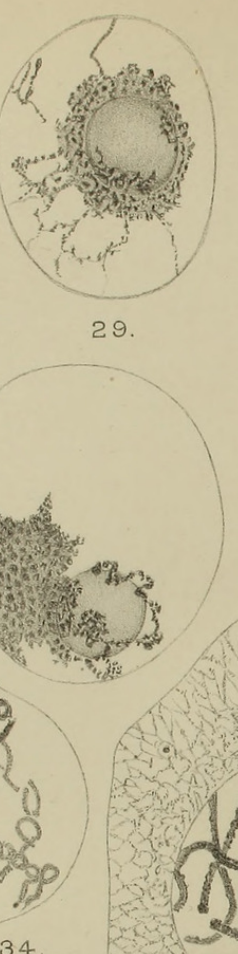

o)

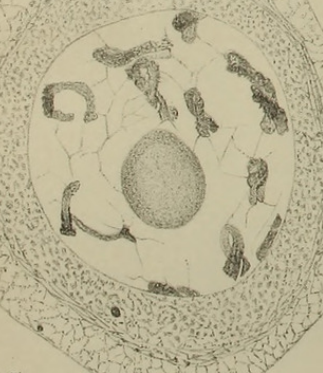

35.
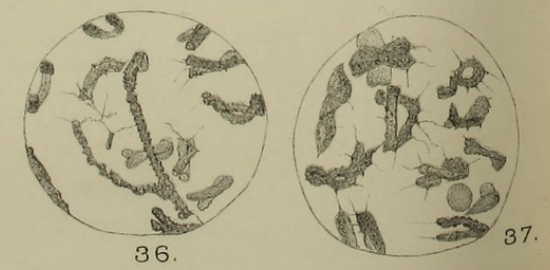
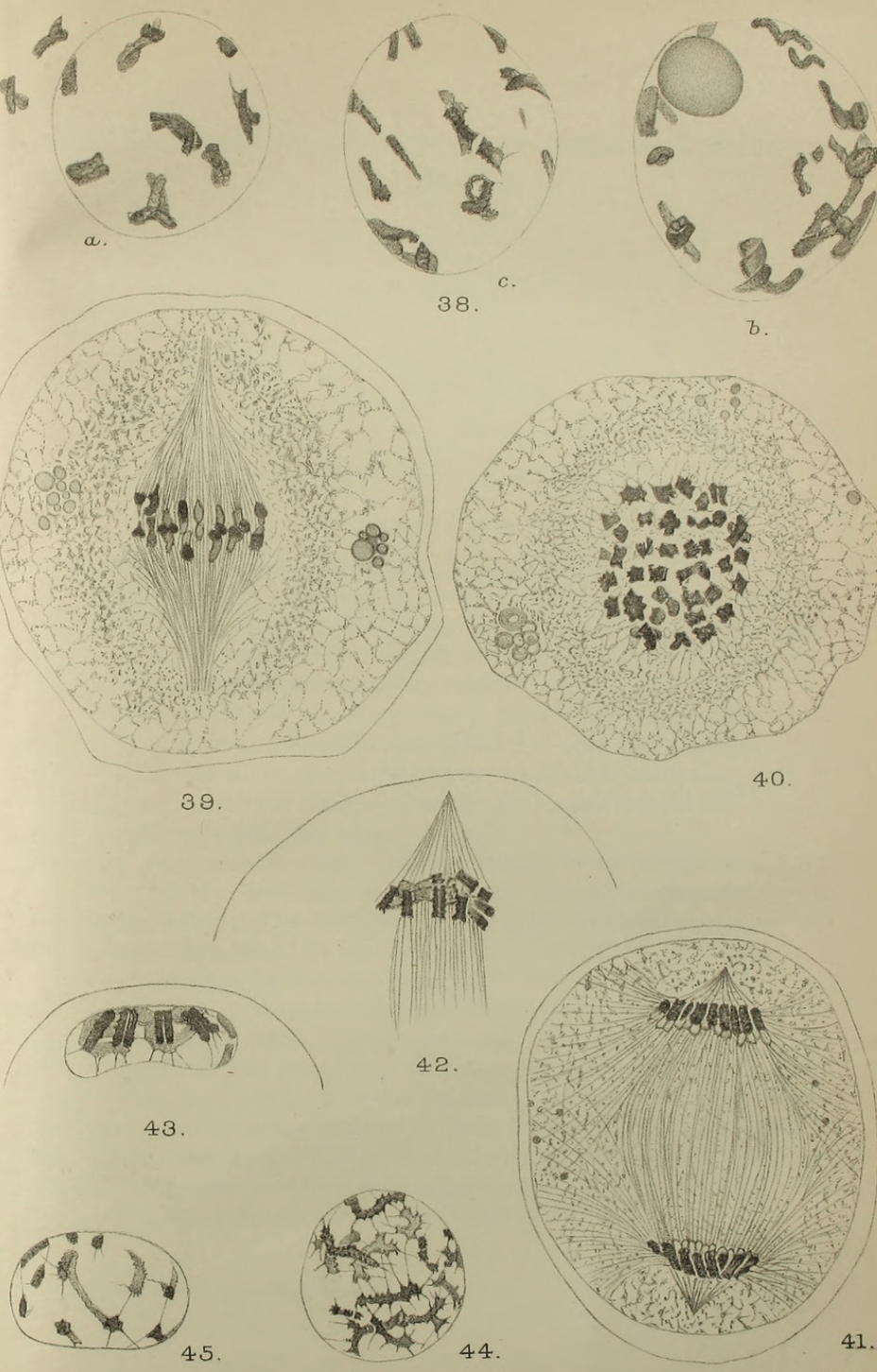

b

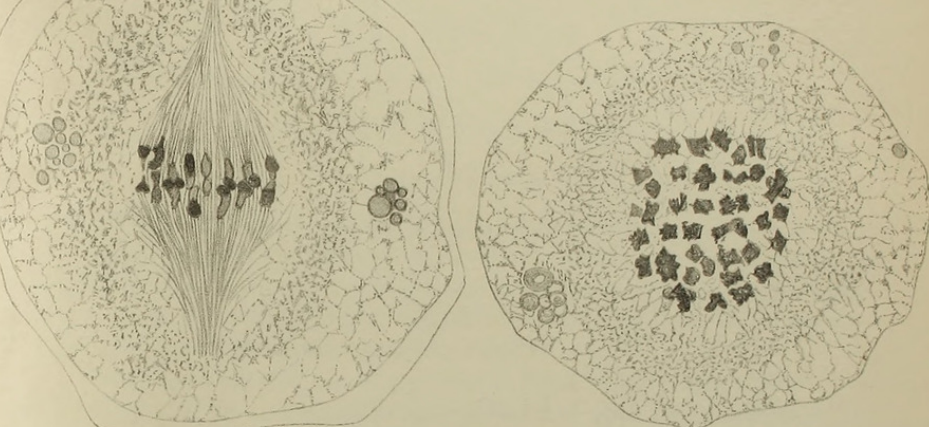

40.

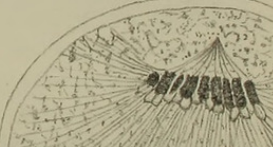

orougen

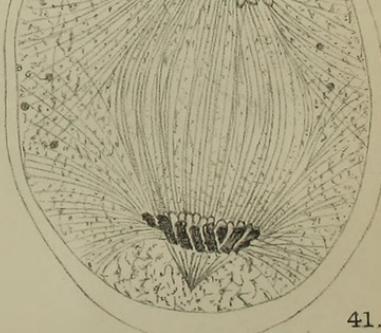

Huth lith et im

MOTTIER - MITOSIS IN POLLEN MOTHER CELLS. 


\section{$2 \mathrm{BHL}$ Biodiversity Heritage Library}

Mottier, David M . 1914. "Mitosis in the pollen mother-cells of Acer negundo, L., and Staphylea trifolia, L." Annals of botany 28, 115-133. https://doi.org/10.1093/oxfordjournals.aob.a089491.

View This Item Online: https://www.biodiversitylibrary.org/item/236856

DOI: https://doi.org/10.1093/oxfordjournals.aob.a089491

Permalink: https://www.biodiversitylibrary.org/partpdf/320012

\section{Holding Institution}

Smithsonian Libraries

\section{Sponsored by}

Biodiversity Heritage Library

\section{Copyright \& Reuse}

Copyright Status: Not in copyright. The BHL knows of no copyright restrictions on this item.

This document was created from content at the Biodiversity Heritage Library, the world's largest open access digital library for biodiversity literature and archives. Visit BHL at https://www.biodiversitylibrary.org. 